\title{
Green Budgeting Policy of Gresik Regency Government
}

\author{
Badrudin Kurniawan* \\ Department of Public Administration \\ Faculty of Social Sciences and Law \\ Universitas Negeri Surabaya \\ Surabaya, East Java , Indonesia \\ badrudinkurniawan@unesa.ac.id
}

\author{
Muhammad Farid Ma'ruf \\ Department of Public Administration \\ Faculty of Social Sciences and Law \\ Universitas Negeri Surabaya \\ Surabaya, East Java, Indonesia \\ muhammadfarid@unesa.ac.id
}

Eva Hany Fanida

Department of Public Administration

Faculty of Social Sciences and Law

Universitas Negeri Surabaya

Surabaya, East Java, Indonesia

evafanida@unesa.ac.id

\author{
Deby Febriyan Eprilianto \\ Department of Public Administration \\ Faculty of Social Sciences and Law \\ Universitas Negeri Surabaya \\ Surabaya, East Java, Indonesia \\ debyfebriyan@gmail.com
}

\begin{abstract}
Green budgeting aims to use public budget to achieve environmental goals. In Local Medium-term Development Plan, Gresik Regency determined direction of environmental development. It was become a reference to do the green budgeting. In fact, some cases shows the regency has low environmental quality. Whereas, there is no previous research regarding the green budgeting in Gresik Regency. Thus, researcher intent to analyse green budgeting policy of Gresik Regency Government using budget tagging technique. The result finds that there is an elaboration of environmental policy direction in Local Medium-term Development Plan 2016-2021 compared to previous period. It leads to add activities number, involved actor and environmental budget enhancement in 2016 and 2017. Then, Environmental Quality Index is uplifted as well. Yet, there is environmental development directions seem to not get more attention.
\end{abstract}

Keywords: Green budgeting, Development Plan, Budget Tagging

\section{INTRODUCTION}

Green budgeting has no single definition. Cremins and Kevany explain it is a new concept which seeks to embed climate and environmental goals within the budgetary process [1]. However, Qibtiyyah, et al have a broader concept, they define it as a process of incorporating sustainable development principles on public budget. It requires an integrated policy which accommodate economic growth, ecological balance, and social justice interests. Furthermore, it also consists of four sectors such as waste management, energy, transportation and land [2]. Consequently, it necessarily involves taking steps that cut across policy sectors and administrative levels [3].

Indonesia government, either central or local, undertake the green budgeting as well. However, it is limited on expenditure aspect, not include revenue one. The government allocate some fund to certain program which promote environmental protection. It is able to provide decision makers, parliament and public with a clearer sense of the potential environmental impacts of budgeting choices [4]. The government usually refers to medium-term development or action plan to conduct it. The directions of environmental policy were listed on the documents.
However, the implementation of green budgeting has not been going well. Central government has never allocate

environmental budget more than one percent for 20102014 period [5]. In local level, government has no good understanding regarding green budgeting. Even some government have low commitment on green budgeting [6]. Result of green budgeting research in West Sumatra Province reveals that in 2013-2016, the government spend less than one percent for environmental protection [7].

Gresik is one of regency in East Java Province undertake the green budgeting. It is reflected on some fund allocated on several environmental protection program. The program held based on Medium-term Development Plan, either in 2011-2015 or 2016-2021 period. Yet, some cases shows precisely low environmental quality.

The several cases include green open space area, hazardous waste production and low air quality. In 2017, the local government did not yet reach the standard area of green open space. Local regulation constitutes the area should be minimum 20 per cent. But the government was able to achieve only 16 per cent [8]. Based on Environmental Management Performance Index of East Java Province released in 2017, Gresik air quality was categorized on lowest level, only 65.81 [9]. Furthermore, in 2015, Environmental Agency of East Java Province launch data that explain Gresik Regency produced more hazardous waste. The amount of hazardous waste in East Java was recorded at 19.4 million tons per year or 1.6 million tons per month, and the hazardous waste generated by Gresik Regency reached 12,906,054 tons/year or 66 percent of the total B3 waste in East Java [10].

Either in other country or Indonesia, there are a little number of green budgeting research. Even there is also a pronounced lack of transparency in most budgetary processes which actively inhibits independent, comparative research [3]. Similarly there is no previous research regarding the green budgeting in Gresik Regency. The government has a lack data as a consideration to formulate next green budgeting policy. Based on the explanation, researchers studied Green Budgeting Policy of Gresik Regency Government. 


\section{METHOD}

This study uses a quantitative-descriptive approach because the research objects are data in the form of numerical, numerical and statistical. The main orientation of this study is to classify, calculate, and construct statistical models to explain the proportion of the budget set by the Gresik Regency Government for the function of environmental protection and preservation. This research is oriented towards reform-oriented research, which is orientation towards change through evaluating applicable policies and recommending certain policy changes.

This research uses secondary data. This data includes document (1) Regional Long-Term Development Plan in 2005-2025 period; (2) Regional Medium-Term Development Plan in 2011-2015 period and 2016-2021 period (3) Gresik Regency Government Accountability Report from 2014 to 2018. This research focuses on the relationship of environmental fiscal policy with regional development policy. Therefore, first, the researchers conducted an analysis of the direction of environmental development in the Regional Medium-Term Development Plan of Gresik Regency in the span of 2014 to 2018. Second, the researchers identified programs related to the direction of development. Third, the researchers calculate the number of activities and budget allocations for the direction of development.

\section{RESULT AND DISCUSSION}

\section{A. The Direction of Environmental Development of Gresik Regency}

Allocating budget on environmental protection program refers to development plan either regional long-term or regional medium-term. The direction environmental development of Gresik Regency was stipulated on development plan. Long-term Development Plan 20052025 list six points such as (1) Industrial development with an environmental perspective; (2) Conservation of water resources; (3) Settlement construction that takes into account environmental functions; (4) Development of sustainable facilities and infrastructure; (5) Management and protection of natural resources; and (6) Enhancing education and environmental awareness campaigns. The directions are relevant to the condition of Gresik regency, namely it has many industries, a large coastal area and population density [11].

The implementation of long-term development plan is divided four stages. Each stage is explained briefly on Medium-term development plan. In 2011-2015 phase, longterm development plan prioritize on natural resource management, environmental preservation and rehabilitation. Furthermore it was relevant to medium-term development plan in 2011-2015 period. On the document, direction of environmental development includes (1) Protection of forests and land; (2) Prevention of environmental pollution; (3) Waste Management and increasing community participation in handling the problem; and (4) Management of energy and mineral resources based on environmental friendly principle [12].

The next phase, 2016-2020, long-term development plan prioritize more aspect on environmental protection effort. The effort prioritize on maintenance of environmental carrying capacity and the ability to restore the environment. Besides, natural resource management and preservation of environmental functions are supported by community

awareness, institutional and spatial planning capacity. Then, medium-term development plan in the periods emphasizes several directions of environmental development namely (1) disaster management; (2) environmental education; (3) environmental friendly fisheries production; (4) environmental friendly transportation; (5) environmental friendly infrastructure development; (6) preservation and conservation of forests, degraded land and natural resources;

(7) sustainable agriculture; and (8) sustainable use of regional energy and mineral resources [13].

\section{B. The Number of Activities and Budget Allocation for the Direction of Environmental Development}

There is differences of environmental development direction between 2014-2015 and 2016-2018. Since 2016, it has been elaborated. It gave consequences to increasing number of activities and involved local department for protecting environment [14]. The following is a table of the number of activities for the direction of environmental development

Table 1 Number of Activities for the Direction of Environmental Development 2014-2015

\begin{tabular}{|l|c|c|}
\hline \multirow{2}{*}{$\begin{array}{c}\text { Direction of Environmental } \\
\text { Development }\end{array}$} & \multicolumn{2}{c|}{$\begin{array}{c}\text { Nctivity } \\
\text { Number }\end{array}$} \\
\cline { 2 - 3 } & 2014 & 2015 \\
\hline Protection of forests and land & 10 & 11 \\
\hline Prevention of environmental pollution & 18 & 18 \\
\hline $\begin{array}{l}\text { Waste Management and increasing } \\
\text { community participation in handling } \\
\text { the problem }\end{array}$ & 6 & 5 \\
\hline $\begin{array}{l}\text { Management of energy and mineral } \\
\text { resources based on environmental } \\
\text { friendly principle }\end{array}$ & 1 & 1 \\
\hline \multicolumn{1}{|c|}{ Total } & 35 & 35 \\
\hline
\end{tabular}

The number of activities either in 2014 or 2015 are no significant difference. The development direction on prevention of environmental pollution has the largest number of activities. The form of activities dominated by procuring waste treatment facilities, river cleaning and workshop about waste management. There are eighteen activities in each year. However, the least number of activities for management of energy and mineral resources based on environmental friendly principle, only one activities. The activities number for protection of forests and land were going up but for waste management and 
increasing community participation in handling the problem was increased.

In the same period, the activities were carried out by four local departments. The departments were consists of Environmental Agency, Local Development Planning Agency, Local Department of Agriculture, Plantation and Forestry, and Local Department of Public Works. Environmental Agency conducted the largest number of activities. It finished twenty four activities in 2014 and twenty three activities in 2015. It indicates that environmental protection was still dominated by one agency whereas environmental issues is complex one.

Table 2 Number of Activities for the Direction of Environmental Development 2016-2018

\begin{tabular}{|l|c|c|c|}
\hline \multicolumn{2}{|c|}{$\begin{array}{c}\text { Direction of Environmental } \\
\text { Development }\end{array}$} & \multicolumn{3}{|c|}{ Activity Number } \\
\cline { 2 - 4 } & 2016 & 2017 & 2018 \\
\hline Disaster management friendly & 0 & 0 & 1 \\
\hline Environmental education & 3 & 1 & 4 \\
\hline $\begin{array}{l}\text { Environmental friendly } \\
\text { fisheries production }\end{array}$ & 1 & 1 & 1 \\
\hline $\begin{array}{l}\text { Environmental } \\
\text { transportation }\end{array}$ & 30 & 24 & 13 \\
\hline $\begin{array}{l}\text { Environmental } \\
\text { infrastructure development }\end{array}$ & 13 & 8 & 3 \\
\hline $\begin{array}{l}\text { Preservation and conservation } \\
\text { of forests, degraded land and } \\
\text { natural resources }\end{array}$ & 1 & 1 & 3 \\
\hline $\begin{array}{l}\text { Sustainable agriculture } \\
\text { Total regional }\end{array}$ & 0 & 0 & 0 \\
\hline $\begin{array}{l}\text { Sustainable use of resty } \\
\text { energy and mineral resources }\end{array}$ & 59 & 42 & 32 \\
\hline
\end{tabular}

Since the direction of environmental development has been elaborated, the number of activities were going up. In 2016, many activities was undertaken toward environmental development, fifty-nine activities. Three greatest number of activities concentrated on environmental friendly infrastructure development; disaster management and preservation and conservation of forests, degraded land and natural resources. The first top dominated by procuring waste treatment facilities activities especially for domestic waste. Then, majority activities are in the form of reservoir construction, flood gates maintenance and river cleaning. The third top are dominated by supplying bio pores and infiltration wells and documentation of environmental information. However, sustainable use of regional energy and mineral resources has no activities at all in 2016-2018.

Many local departments involved in the activities toward environmental development directions. The departments consist of Environmental Agency; Local Department of Public Work; Local Department of Agriculture, Plantation and Forestry; Local Department of Fishery; Local Department of Industry and Trade, Local Development Planning Agency; and Local Department of
Public Health. However, only two departments do the most activities, namely Environmental Agency and Local Department of Public Works.

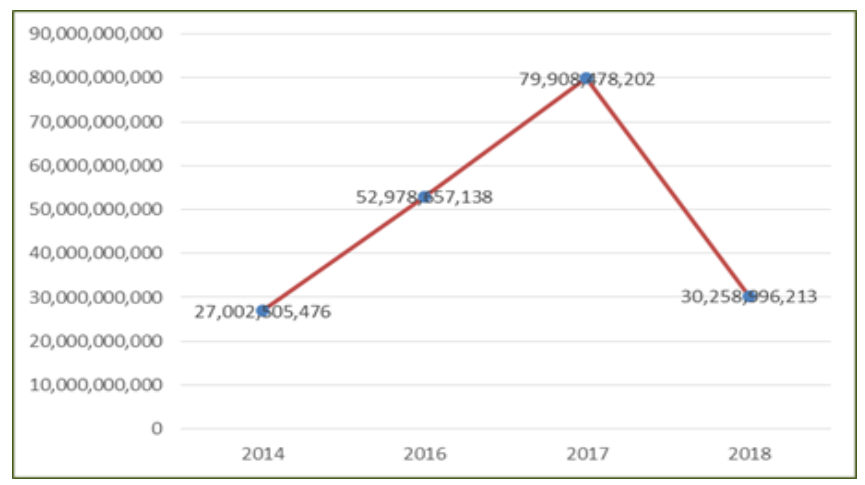

Figure 1 Environmental Expenditure (2014, 2016, 2017 and 2018)

Start from 2014 until 2018, environmental expenditure has fluctuated. In 2014 and 2015, government spent more on prevention of environmental pollution and waste Management and increasing community participation in handling the problem. The expenditure jumped sharply in 2016 because local government elaborated environmental development direction. Environmental expenditure reached 52,978,657,138 rupiah. This increase continued until 2017. The expenditure grew one until three percent each years. In the period, the direction of environmental development spent more budget were disaster management and environmental friendly infrastructure development. However, in 2018, the expense as going down.

\section{Trend of Environmental Quality in Gresik Regency}

Gresik Regency Government measures environmental quality using Environmental Quality Index. The indicators used in calculating the index are (1) Index Water Quality/Pollution; (2) Air Quality/Pollution Index, (3) Forest/Land Cover Index. Air Pollution Index with a weight of 30\%, Air Pollution Index 30\% and Forest/Land Cover Index $40 \%$. Below is graph of Environmental Quality Index 2015-2018.

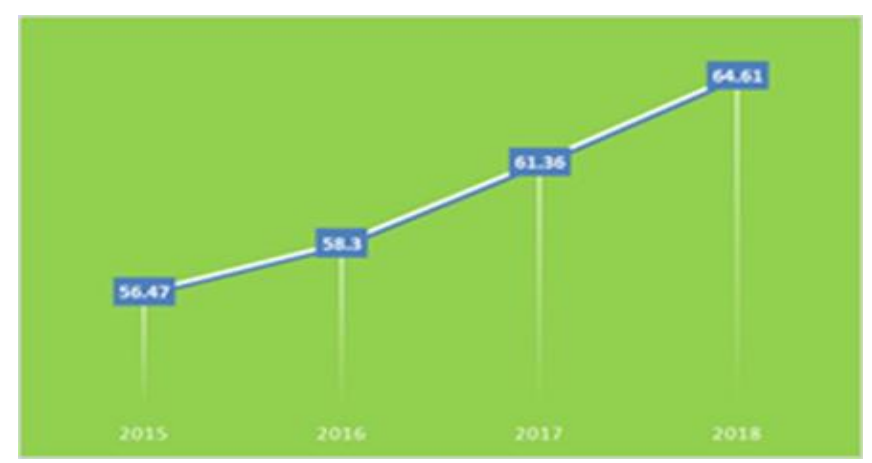

Figure 2 Environmental Quality Index (2015-2018)

The graph depicts the enhancement of environmental quality index form 2015 until 2018. Each year the index 
always increases even in 2018 when environmental expenditure decreased, the index was climbing. In 2015 the index reached 56.47, in 2016 raised up 58.3, in 2017 achieved 61.36 and in 2018 climbed up 64.61. It indicates that spending more budget for environmental development has positive impact for the environmental quality.

\section{CONCLUSION}

Gresik Regency Government has implemented green budget policy. The government spent the budget for environmental development. The allocation refers to the direction of environmental development listed on either longterm or medium term development plan document. In the range 2014-2018, an elaboration of the direction was happened. It gave consequences the rise of activities number and involved agencies. Moreover, environmental expenditure went up in period 2014-2017. But it was declined in 2018.

In 2014-2018, Environmental Agency still dominated the activities for reaching environmental development direction. Although more agencies have been involved since 2016 yet the agency have the greatest activities number. Whereas, environmental development is a complex issues. Beside there is no activities for attaining one of environmental development direction namely sustainable use of regional energy and mineral resources.

Although the green budget policy has some weakness, the environmental quality was improved in 2015-2018. Gresik Regency Government uses Environmental Quality Index to identify the environmental quality. As long four years, 2015-2018, the index has continued to rise. It indicates that spending more budget for environmental development has positive impact for the environmental quality.

Gresik Regency Government need to raise the quantity and quality activities for environmental development. The government should add activities for achieving sustainable use of regional energy and mineral resources. Furthermore, other agencies, not only environmental agency, need to add activities for environmental protection. The government should improve the quality of activities such as increasing green open space area to preserve water catchment area and recovering river ecosystem to control water flow.

\section{ACKNOWLEDGMENT}

Thanks to State University of Surabaya which gave the research grant. Also, thanks to Gresik Regency.

\section{REFERENCES}

[1] A. Cremins, L. Kevany, An introduction to the implementation of Green Budgeting in Ireland, Staff Paper, Irish Government Economic \& Evaluation Service, 2018.

[2] R. M. Qibtiyyah et al, Mengungkap permasalahan stakeholder pada implementasi penganggaran hijau (in English: Disclose stakeholder issues in implementing green budgeting), Penganggaran Hijau Newsletter, Faculty of Economic and Business
University of Indonesia - Millenium Challenge Account Indonesia (MCAI), 2016.

[3] A. J. Jordan, A. Lenschow, Innovation in Environmental Policy? Integrating the Environment for Sustainability, Edward Elgar, 2008.

[4] OECD, Budgeting for environmental and sustainable development, Government at A Glance, The Organisation for Economic Co- operation and Development, 2019.

[5] Indonesia WWF Green Economic Team, Buku pedoman penandaan anggaran hijau di daerah (in English: Guide book for budget tagging in local), World Wildlife Fund-Indonesia, 2017.

[6] R. M. Qibtiyyah et al, Laporan kegiatan (in English: Activities report), Penganggaran Hijau Newsletter, Faculty of Economic and Business University of Indonesia - Millenium Challenge Account Indonesia (MCAI), 2015

[7] Perkumpulan Integritas and Auriga Nusantara, Analisis kebijakan anggaran lingkungan hidup menggunakan budget tagging di provinsi sumatera barat (in English: Policy analysis of environmental budget using budget tagging in east sumatera province), Study Report,

Perkumpulan Integritas and Auriga Nusantara, 2018

[8] Gus and Sal. 2017. Gresik Butuh Tambah Ruang Terbuka Hijau (in English: Gresik Needs More Green Open Space). Accessed on May 2nd , 2020 from https://duta.co/gresik-butuh-tambah-ruang-terbukahijau

[9] D. A. Sektiawan et al, Dokumen informasi kinerja pengelolaan lingkungan hidup daerah provinsi jawa timur (in English: Information document of environmental management performance in east java province), Executive Summary, Dinas Lingkungan Hidup Provinsi Jawa Timur, 2018

[10] A. D. J. Pandia, Capacity building di dinas lingkungan hidup kabupaten gresik (studi tentang penanganan limbah b3 di kabupaten gresik) (in English: Capacity building in environmental agency of gresik regency: study on hazardous waste management in gresik regency Accessed on May 2nd, 2020 from http://repository.unair.ac.id/74553/3/JURNAL_Fis.A N.46\%2018\% 20Pan\%20c.pdf.

[11] Long-term Development Plan 2005-2025 in Gresik Regency

[12] Medium-term Development Plan 2011-2015 in Gresik Regency

[13] Medium-term Development Plan 2016-2020 in Gresik Regency

[14] Gresik Regency Government Accountability Report $2014-2018$ 